\title{
Limitations to Freedom of Religion or Belief in Denmark
}

\author{
Eva Maria Lassen \\ Senior Researcher, Danish Institute for Human Rights \\ eva@Humanrights.dk
}

\begin{abstract}
The article analyses legislative changes in the area of freedom of religion or belief in Denmark between 2014 and 2018. Recent legislation has placed pressure particularly on religious minorities to limit certain religious manifestations, and it is possible to trace a certain "juridification" of freedom of religion, by which the values underlying freedom of religion according to international standards are not always fully reflected. Additionally, there is a tendency to address societal concerns by means of legal interventions. The article argues that by making increased use of soft law developed by the EU, the Council of Europe and the UN, Danish lawmakers would be able to reach a more comprehensive understanding of freedom of religion or belief as well as include non-legal solutions to societal concerns. It further argues that while Denmark's national (Lutheran) church possess the majority of constituents, nonetheless its privileged position may paradoxically strengthen freedom of religion for religious minorities.
\end{abstract}

\section{Keywords}

Denmark - freedom of religion or belief - limitation clauses

\section{Introduction}

In the last two decades, developments in the religious demography of Denmark have increasingly gone hand-in-hand with rising pressure-both legal and non-legal-to limit specific religious manifestations, particularly those of 
religious minorities. ${ }^{1}$ This tendency, which has wider implications for the freedom of religion or belief for all, is the main focus of the present article.

The article begins by describing the religious demographic landscape in Denmark and positioning the regulation of religious communities within the framework of the Danish constitution. In this context both the privileged position of the National Evangelical Lutheran Church, the Folkekirke ("The People's Church"), and the law of 2017 regulating registered faith communities outside of the Folkekirke will be outlined, with a view to determine both the protections and limitations of freedom of religion or belief that are embedded in the constitutional framework.

Based on a summary of Denmark's international obligations in the field of freedom of religion or belief, including the European Convention of Human Rights (ECHR), the article then focusses on recent interventions in freedom of religion or belief, specifically examining legislative measures initiated in the period between 2014 and 2018. The article then focusses on societal factors that influence legal as well as non-legal pressure on freedom of religion or belief, and finally suggests ways in which to further the protection of this freedom in Denmark.

The article has made use of acts, pending legislative proposals, administrative orders and circulars. Briefs submitted by faith communities and lifestance associations on legislative proposals concerning possible limitations of freedom of religion or belief have been included, although it should be noted that relatively few faith communities submit such briefs. Also included are legal briefs submitted to Parliament by the Danish Institute for Human Rights (Denmark's National Human Rights Institution) on specific legislative proposals concerning potential limitations of freedom of religion or belief as well as annual status reports of the Institute. In addition, the present article has made use of debates in the media as well as Parliamentarian debates.

In 2016, the UN Special Rapporteur on freedom of religion or belief, Heiner Bielefeldt, paid a country visit to Denmark. "Country visits" belong to the category of UN mechanisms, which aim to support Member States in complying with the international human rights conventions. Bielefeldt's findings and recommendations were presented in a report to the UN Human Rights Council in

1 Eva Maria Lassen, 'The EU and Religious Minorities under Pressure', 1 The European Yearbook on Human Rights (2016) pp. 159-172.

2 Denmark was the only Western state that the Special Rapporteur visited on a formal country visit during his term (2010-2016). 
early $2017 \cdot{ }^{3}$ While the report and its recommendations are not legally binding on the State, they offer a unique opportunity to look at limitations on freedom of religion or belief in Denmark using international standards. A prominent characteristic of Bielefeldt's report is that it adopts an approach to freedom of religion or belief that goes beyond the law strictly speaking and looks more broadly at freedom of religion in the context of societal structures and values.

Historical, religious, cultural and political factors have influenced the position of religion in Danish society, affecting, for instance, the position of religious minorities vis-à-vis the majority and perceptions of what constitutes Danish identity. Historically, Denmark has been a religiously homogenous society: the vast majority of the population belonged to the Folkekirke. However, the demographic landscape has changed dramatically over the last 50 years. Today, approximately $76 \%$ of the Danish population of approximately 5.8 million belongs to the Folkekirke. Whereas, for instance, in 1970 only ten Christian faith communities of various denominations outside the Folkekirke were "acknowledged", today there are more than a hundred. The number of adherents to religious denominations outside the Folkekirke is uncertain, as only members of the Folkekirke are registered by the State. The oldest non-Christian community in Denmark is the Jewish Community, which was recognised by Royal Decree in 1684. The estimated number of Jews today is 700o. The largest non-Christian minority religion is Islam. Prior to the 1970s there were very few Muslims in Denmark; whereas today the number of Muslims living in Denmark is estimated to be between 280,000 and $310,000 .{ }^{4} \mathrm{~A}$ fraction of the population belong to other religions, for instance, Buddhism and the Bahá'i as well as associations based on old Nordic mythology. Approximately $16 \%$ of the population do not belong to a registered faith community. ${ }^{5}$

3 Human Rights Council, Report of the Special Rapporteur on freedom of religion and belief on his mission to Denmark, Heiner Bielefeldt (A/H Rc/34/5o/Add.1).

4 Center for Samtidsreligion, Religion i Danmark 2017 (Aarhus: University of Aarhus, 2017), p. 6.

5 The Danish Institute for Human Rights, Religion. Status 2015-16 (Copenhagen: The Danish Institute for Human Rights, 2016), pp. 10-11. 


\section{The Constitutional Framework for Freedom of Religion in Denmark}

\subsection{The Folkekirke}

On his country visit to Denmark, the UN Special Rapporteur Heiner Bielefeldt observed a phrase often used in Danish discourse, namely the expression that 'there is religious freedom in Denmark but not religious equality' ${ }^{6}$ This phrase sums up the state of affairs as laid down in the Danish constitution. The constitution dates back to 1849 and was last amended in 1953. The human rights catalogue of the constitution is limited and primarily-although not exclusively - protects the "classical freedom rights", including freedom of religion.

The Danish National Evangelical Lutheran Church, in the constitution called the "Folkekirke", holds a constitutionally privileged position and is supported by the State, financially and otherwise. Whereas the two other Scandinavian countries have loosened the bond between state and church in recent decades, Denmark has not. As a result, the State regulates religious denominations outside of the Folkekirke differently than its own national church.

Theologically, the Folkekirke is all-encompassing, embracing a wide spectrum of views from the very liberal to the very conservative. Generally speaking, the church is liberal and assumes many norms and values of society at large but in such a way as to give room for the co-existence of other theologically founded positions. For example, same-sex marriage is allowed in the Folkekirke. At the same time, priests are entitled by law to be exempt from the obligation to marry same-sex couples if it is against their personal convictions.

The privileged position of the Folkekirke may have negative effects on freedom of religion or belief in Denmark in three areas. Firstly, all citizensincluding those who are not members of the Folkekirke-are dependent in some respects on the services of the Folkekirke and financially contribute to the Church. The Supreme Court considered this matter in 2007. The case concerned firstly the birth registration of a child of Catholic parents at the local register of the parish of the Folkekirke, acting as National Register; secondly, it addressed the obligation of the parents to contribute indirectly to the Folkekirke via their general taxes (in Denmark all taxpayers, regardless of their

6 Bielefeldt, supra note 3, para. 9 . 
religious affiliation, financially contribute to the Folkekirke, which is partially state-funded). The Court found that freedom of religion was not violated. ${ }^{7}$

Second, in addition to its privileged position, there is also the question of whether freedom of religion or belief is unduly limited within the Folkekirke. This was considered by the Supreme Court in 2017. The case concerned whether a new act allowing priests of the Folkekirke to marry persons of the same gender was invalid in the context of the Constitution, constitutional customs, and the ECHR. Central to the case was the structural architecture framing the State-Church relationship, according to which the government and Parliament have the decision-making power over the Folkekirke. The Supreme Court found that the act was valid and did not violate the constitution nor the freedom of religion of belief as laid down in the ECHR. ${ }^{8}$

Third, it is debatable whether the exclusive bond between the Danish State and the Folkekirke creates problems related to both societal inclusion of all citizens and perceptions of what constitutes Danish identity.

Finally, it should be mentioned that there is an overwhelming reluctance in Danish society and among politicians to loosen the bond between the Folkekirke and the State. Such a change would also require a constitutional amendment, which in Denmark is exceedingly difficult and extraordinarily rare. Parliament is generally averse to initiating amendments to the constitution - the last one having been made in 1953. Instead, the State has taken steps to rectify some of the above-mentioned human rights challenges within the current constitutional framework. For instance, some of the issues related to the national registration of births have been resolved in recent years. While the Folkekirke is still in charge of the national registration, it is no longer necessary for parents to meet up in the church to have their child registered (the midwife may have the child registered or-if the child is not born in a hospital—it can be done electronically through the local authority's website).

\subsection{Milestone Act: Regulating Faith Communities Outside the Folkekirke}

In 2017, the Danish Parliament adopted a new act, 'Act regulating faith communities outside the Folkekirke' (Trossamfundsloven). ${ }^{9}$ The act provides a framework for the regulation of faith communities outside the Folkekirke wishing to

7 Højesteret, Dom om fødselsregistrering og statstilskud i folkekirken, sag no. 159/2016, afgjort 2007, <http://www.hoejesteret.dk/hoejesteret/nyheder/pressemeddelelser/Pages/ Foedselsregistreringogstatstilskudtilfolkekirken.aspx $>$, accessed 30 October 2019.

8 Højesteret, Dom om vielse af personer af samme køn, sag no. 159/2016, afgjort 2017, <http://www .hoejesteret.dk/hoejesteret/nyheder/Afgorelser/Pages/Vielseaftopersonerafsammekoen .aspx $>$ accessed 30 October 2019 .

9 Kirkeministeriet, Lov om trossamfund uden for folkekirken, No. 1533, 19 December 2017. 
be acknowledged by the State. The act is a milestone in Danish legal history and the history of religion in Denmark. Historically, the regulation of faith communities outside the Folkekirke was rather ad hoc and non-transparent, not consistently administered by changing ministries. In addition, there was a legal distinction between "acknowledged" (old Christian communities and in, addition, the Jewish community) and "recognised" faith communities (all faith communities registered after 1970) with slightly different rights.

The new act promises to be an important step towards "normalising" Danish society as one made up of individuals belonging to different faiths. The act offers a coherent regulation, which may ensure a better functioning and transparent regulation of these communities within the Danish constitutional framework. In addition, from now on, all faith communities outside the Folkekirke, which fulfil certain criteria, may obtain the same status as "acknowledged" faith communities. Religious communities are not obliged to request the status of an acknowledged faith community. However, tax exemption and the right to perform marriages with civil validity are only given to registered faith communities, and hence a big proportion of faith communities wish to acquire this status.

Overall, the new act does not contain substantial criteria for acquiring the status of "acknowledged faith community" which potentially may be problematic from the point of view of freedom of religion or belief. Two such issues should be highlighted, however. First, the act does not consider the freedom of religion or belief of children as laid down in the UN Convention on the Rights of the Child. The new act allows parents to decide their child's membership in a given religious community until the age of 18 - without the child's consent. ${ }^{10}$ Prior to the adoption of the law, Parliament did not consider the Convention on the Rights of the Child, in particular Articles 5, 12 and 14, with its emphasis on the gradual participation of children in decisions relevant to them. In addition, there is an issue of possible discrimination: children have more rights when it comes to membership consent of the Folkekirke (here parents cannot decide on the membership of a child from the age of 15 without the consent of the child) than children vis-à-vis membership of other faith communities (here the parents can in principle make decisions on the child's membership until the age of 18). ${ }^{11}$

10 Høring over forslag til lov om trossamfund uden for folkekirken, 22 August 2017, Danish Institute for Human Rights, legislative brief, pp. 2-3, <www.menneskeret.dk/sites/men neskeret.dk/files/o8_august_17/hoeringssvar_om_forslag_til_lov_om_trossamfund _uden_for_folkekirken.pdf>, accessed 12 April 2019.

Ibid., p. 3. 
Second, as the title indicates the new act does not include non-religious lifestance associations. Article 67 of the Danish constitution dates back to 1849 and expresses an understanding of freedom of religion which is narrower than that in modern international law. It follows that life-stance associations are not covered by the constitution's Article 67 , a fact that is reflected in the new law. Heiner Bielefeldt stressed the importance of interpreting freedom of religion in light of international human rights standards, ${ }^{12}$ and recommended that the new law, which was under way at the time of his visit, include life-stance organisations 'not based on a belief in God or a transcendent power.'13 This recommendation was not followed.

\section{4 \\ Limitations to Freedom of Religion or Belief and International Obligations}

Denmark is a liberal democracy with high human rights standards and a wellfunctioning rule of law. The Danish State has entered into numerous conventions and treaties on human rights protection under the framework of the UN, the Council of Europe and the European Union. Denmark has ratified the International Covenant on Civil and Political Rights (ICCPR) and the main international conventions, having incorporated the ECHR into Danish law in 1992. As an EU Member State, Denmark is a party to the EU Charter for Fundamental Rights and bound by EU law in instances such as directives concerning freedom of religion or belief in the workplace.

The Danish courts primarily consider ECHR and the case law of the European Court of Human Rights (ECtHR) when deliberating international standards for freedom of religion or belief. By contrast, the explicit use of the ICCPR by Danish courts is exceedingly sparse. In a survey carried out under the auspices of the Danish Ministry of Justice, this was only the case eight times between

12 'Both the European Court of Human Rights and the UN Human Rights Committee in charge of monitoring the International Covenant on Civil and Political Rights (ICCPR) have developed a jurisdiction that understands freedom of religion or belief more broadly. According to the Human Rights Committee, Article 18 of the ICCPR protects "theistic, non-theistic and atheistic beliefs, as well as the right not to profess any religion or belief" ... In other words, freedom of religion or belief covers the whole range of identity-shaping convictions and conviction-based practices, beyond traditional forms of monotheistic faith and worship. For Article 67 of the Constitution to remain in keeping with the meanwhile established understanding of European and international human rights law, it should be interpreted in a broad and inclusive way.' Bielefeldt, supra note 3 , para. 44 .

Ibid., para. $75(\mathrm{j})$. 
1 January 2001 and 1 January $2014 \cdot{ }^{14}$ In this period, the Supreme Court only once dealt with freedom of religion with explicit reference to the Covenant. Since 2014, only two Supreme Court judgments have related to freedom of religion. The first case concerned whether a new act, allowing priests of the Folkekirke to marry persons of the same gender, was invalid (see earlier discussion). The applicants did not refer to ICCPR, and the Supreme Court did not consider the Covenant. The Court found that the act was valid. ${ }^{15}$

The other case dealt with the question of whether Danish authorities had violated Article 9 of the ECHR by prohibiting the import of ayahuasca wine containing the psychedelic drug DMT for use in religious ceremonies. The High Court considered the case in the context of the ECHR but also, inter alia, the ICCPR. The Supreme Court did not consider the case in the context of the ICCPR but in the context of the ECHR and the case law of the ECtHR, which had made a judgment on the same issue (import of ayahuasca wine for religious reasons). The Supreme Court, in accordance with the case law of the ECtHR, found that freedom of religion or belief had not been violated, as the prohibition was anchored in the need to protect public health and order. ${ }^{16}$

\section{$5 \quad$ Limiting Freedom of Religion or Belief: Legal and Societal Pressures}

Throughout the modern history of Denmark, starting with the establishment of the first democratic constitution in 1849, a high degree of tolerance towards the manifestation and practice of religious traditions as well as pragmatic approaches to religious diversity existed side by side with the privileged position of the Danish Folkekirke. This state of affairs is challenged today, where developments in the religious demography increasingly go hand in hand with pressure - of both a legal and non-legal nature-on religious minorities to limit particular religious manifestations. Thus in recent years, religious symbols, rituals and practices have been high on the political agenda and subject to much debate in the media. ${ }^{17}$ Although not exclusively so, it is primarily

\footnotetext{
14 Justitsministeriet, Betcenkning om inkorporering $m v$. inden for menneskeretsområdet, No. 1546 (København, 2014), pp. 51-56.

15 Højesteret, supra note 8.

16 Højesteret, Dom om afslag på tilladelse til import af vin var ikke i strid med EMRK artikel 9, sag no. 83/2017, afgjort 2018, <http://www.hoejesteret.dk/hoejesteret/nyheder/ Afgorelser/Pages/AfslagpaatilladelsetilimportafvinvarikkeistridmedEMRKartikelg.aspx $>$, accessed 30 October 2019.

17 Lassen, supra note 1, pp. 159-172.
} 
non-Christian practices which are the focus of restrictions, in particular those of Jews and Muslims (as debates on male circumcision demonstrate, see below). In what follows, important legislative measures taken between 2014 and 2018 will be outlined, continued by a discussion of societal factors which may further contribute to pressure on freedom of religion or belief.

\subsection{Ritual Slaughter}

The prohibition of religious slaughter without prior numbing (a Jewish and Muslim practice) was introduced by an administrative order in 2014. ${ }^{18}$ From international soft law mechanisms, concern has been raised over the ban. Thus, the Special Rapporteur on freedom of religion or belief in his report on Denmark recommended that the Danish government 'reconsider the ban on ritual slaughter without prior stunning. ${ }^{19}$ Equally, the Advisory Committee on the Framework Convention for the protection of national minorities in 2015 called 'on the authorities to adopt a religiously sensitive approach to the question of ritual slaughter of animals and consider, in consultation with those concerned, solutions which take into account religious freedom. ${ }^{20}$

\subsection{Five Acts Targeting "Religious Preachers Who Seek to Undermine Danish Law and Values"}

In March 2016, a national television broadcast showed a programme which presented imams in a particular mosque preaching views contrary to Danish law. The programme triggered heated political debates. On $3_{1}$ May 2016, and as a result of these debates, the government (Denmark's Liberal Party), the Social Democrats, the Danish People's Party and the Conservatives entered into a political agreement on initiatives 'aimed at religious preachers who seek to undermine Danish laws and values and who support parallel conceptions of law'.21 The agreement resulted in five bills, all of which were adopted in late 2016 and early 2017: Bill for an Act to amend the Marriage and Dissolution of Marriage Act (Decorum requirement and mandatory course

18 Miljø- og Fødevareministeriet, Bekendtgørelse om slagtning og aflivning af dyr, No. 135 (København, 14 February 2014).

19 Bielefeldt, supra note 3, para. 75 (f).

20 Council of Europe, Advisory Committee on the Framework Convention for the protection of national minorities. Fourth Opinion on Denmark adopted on 20 May 2014, published on 20 January 2015, section 70 .

21 See Lars Grassmé Binderup and Eva Maria Lassen, 'The Blasphemy Ban in Denmark', in J. Temperman and A. Koltay (eds.), Blasphemy and Freedom of Expression: Comparative, Theoretical and Historical Reflections after the Charlie Hebdo Massacre (Cambridge: Cambridge University Press, 2017), pp. 450-451. 
in Danish family law, freedom and democracy); ${ }^{22}$ Bill to amend the Criminal Code (Criminalisation of explicit approval of certain criminal acts in the context of religious training);23 Bill to amend the Act on Non-formal Education and Democratic Voluntary Activity and the Tax Assessment Act (Measures against associations counteracting or undermining democracy or fundamental freedoms and human rights);24 Bill to amend the Aliens Act (Introduction of a public sanction list of foreign religious preachers, etc., who may be denied entry into Denmark); ${ }^{25}$ Bill to amend the Aliens Act (Mandatory course in Danish family law, freedom and democracy for religious preachers etc., and promissory declaration of compliance with Danish legislation). ${ }^{26}$

The bills raise concern regarding limitations of freedom of expression and potentially freedom of religion or belief. Notably, the Criminal Code has been amended so that statements expressing views contrary to Danish law are criminalised regardless of whether they are expressed publicly or privately. Moreover, the statements targeted by the new acts are those expressed by religious preachers but not by other leaders with comparable authority (for instance leaders of politically extreme movements). This presents a risk of disproportionate discrimination. Also, the acts contain certain ambiguities, which make it difficult for individuals to assess whether their actions would be considered unlawful. In addition, although the bills intend to target a specific group of presumably few religious leaders, the legislation has the potential to throw suspicion on all religious communities and their leaders.

\subsection{The "Burka Ban"}

In the spring of 2018, the Danish Parliament passed a ban on face covering. ${ }^{27}$ The ban applies, inter alia, to women who wear either the burka or niqab.

22 Kirkeministeriet, Lov om cendring af lov om cegteskabs indgåelse og opløsning (Decorumkrav og obligatorisk kursus i dansk familieret, frihed og folkestyre), No. 1729 (København, 27 December 2016).

23 Justitsministeriet. Lov om cendring af straffeloven (Kriminalisering af udtrykkelig billigelse af visse strafbare handlinger som led i religiøs oplcering), No. 1723 (København, 27 December 2016).

24 Kulturministeriet. Lov om cendring af folkeoplysningsloven og ligningsloven (Indsats mod foreninger, som modarbejder eller underminerer demokrati eller grundlceggende friheds- og menneskerettigheder), No. 1553 (København: 13 December 2016).

25 Udlændinge- og Integrationsministeriet, Lov om cendring af udlcendingeloven (Indførelse af en offentlig sanktionsliste over udenlandske religiøse forkyndere m.fl., som kan udelukkes fra at indrejse), No. 1743 (København, 27 December 2016).

26 Udlændinge- og Integrationsministeriet, Lov om cendring af udlcendingeloven (Obligatorisk kursus i dansk familieret, frihed og folkestyre for religiøse forkyndere m.fl. og løfteerklaring om overholdelse af dansk lovgivning), No. 249 (København, 20 March 2017).

27 Justitsministeriet,Lovom cendring afstraffeloven(Tildcekningsforbud), No. 717 (København, 8 June 2018). 
The so-called burka ban is based on the alleged need to protect the rights and freedoms of others ( $c f$. Article 9(2) ECHR). Danish legislators followed the judgments of the European Court of Human Rights, by stressing the need to introduce the ban to enhance social cohesion and the concept of "living together". 28 Among the human rights issues raised in connection with the ban is the risk of social exclusion of the women concerned. ${ }^{29}$

\subsection{Handshake as a Precondition for Citizenship}

In December 2018 Parliament passed a bill concerning the acquisition of citizenship. ${ }^{30}$ In it a new element was added, namely a ceremony for the acquisition of citizenship. During the ceremony, the applicant would be obliged to shake hands with the person authorised to grant citizenship. In its preparatory work, the Ministry considered the compatibility of the handshake as a precondition for citizenship in view of the European Convention of Human Rights. Although the Ministry referred to the margin of appreciation as applicable to the State's granting of citizenship, it did not explicitly consider the proposal in the context of Article 9(2). ${ }^{31}$ However, it can be assumed that the proposal is implicitly linked to the limitation clause "the rights and freedoms of others": the reasoning underlying the proposal is that 'a handshake is an expression of respect', and respect is a 'fundamental societal value' in Denmark. ${ }^{32}$ Hence, the

28 See S.A.S. v. France, 1 July 2014, European Court of Human Rights, No. 43835/11; Dakir v. Belgium, 11 July 2017, European Court of Human Rights, No. 4619/12; Belcacemi and Oussar v. Belgium, 11 July 2017, European Court of Human Rights, No. 37798/13.

29 See Høringssvar vedr. Udkast til forslag til lov om cendring af straffeloven (Tildcekningsforbud), 6 March 2018, Danish Institute for Human Rights, legislative brief, <https:// menneskeret.dk/sites/menneskeret.dk/files/o3_marts_18/hoeringssvar_til_udkast_til_ forslag_til_lov_om_aendring_af_str._pdf >, accessed 12 April 2019 .

30 Udlændinge- og Integrationsministeriet, Forslag til lov om cendring af lov om dansk indfødsret og lov om danskuddannelse til voksne udlcendinge m.fl. (Henloeggelse til kommunalbestyrelserne af grundlovsceremonier, forhøjelse af gebyr for ansøgning om dansk indfødsret ved naturalisation og fastscettelse af ncermere regler om udlcendinges fravcer $i$ undervisning $i$ dansk m.v.), No. 1735 (København, 27 December 2018).

$31 \quad H ø r i n g$ over udkast til forslag til lov om cendring af lov om dansk indfødsret og lov om danskuddannelse til voksne udlcendinge m.fl. (Henlceggelse til kommunalbestyrelserne af ceremoniel underskrivning af grundloven mv., forhøjelse af gebyr for ansøgning om dansk indfødsret ved naturalisation samt fastscttelse af ncermere regler om udlcendinges fravcer i undervisning i dansk m.v.), 5 October 2018, <https://menneskeret.dk/sites/menneskeret .dk/files/afgoerelsesdatabase_2018/o8-10-2018_2_hoeringssvar_til_udkast_til_forslag _til_lov_om_aendring_af_lov_om_dansk_indfoedsret_og_lov_om_danskuddannelse_til_ voksne_udlaendinge_m.fl.pdf>, Danish Institute for Human Rights, legislative brief, accessed 15 May 2019. 
Ministry concluded that the handshake as a condition for citizenship pursue a legitimate aim.

The precondition of the handshake to acquire citizenship bears the risk of indirect discrimination on account of religion, as for instance some Muslims do not shake hands with persons of the opposite sex outside the immediate family. ${ }^{33}$ In addition, there is a risk that the law would have negative consequences in an entirely arbitrary manner: the gender of the mayor and the applicant respectively could influence an applicant's decision (on religious grounds) to forego the handshake as a condition of citizenship.

\subsection{Abolishing the Ban on Blasphemy}

While heretofore this article's focus has been on the limitations to freedom of religion or belief, in recent years, there has been another legal initiative moving in a different direction, namely the abolition of the blasphemy ban. Until 2017, Danish law included an article criminalising blasphemy. Thus, Article 140 in the Danish Penal Code stated: 'whoever, in public, mocks or scorns the religious doctrines or acts of worship of any lawfully existing religious community in this country, shall be liable to a fine or imprisonment for a term not exceeding four months' ${ }^{34}$ The provision had historical roots in the autocratic rule of Denmark. The last conviction based on the blasphemy ban occurred in 1946 . Between 1971 and 2017, there was no prosecution based on the provision.

In recent years, attempts to abolish the blasphemy ban were made on several occasions, partly because the continued inclusion of Article 140 in Danish law was controversial from a human rights perspective. Until 2017, such attempts were unsuccessful. The reasons why Denmark did not follow the trend of a majority of EU Member States, including those with which Denmark normally compares itself, are complex. In 2015, the political decision to retain the ban was largely based on the fear of violent reactions to religious insult, including terrorism. In other words, the limitation of freedom of expression was based on concerns for public order and safety. Amongst religious faith communities, concern was expressed that the abolition might negatively affect the status of minority religions. The Jewish community in Denmark, amongst others, expressed this concern, which was accentuated by the fact that a number of religious minorities (especially Jewish and Muslim) were becoming increasingly vulnerable to harassment and racism. ${ }^{35}$

33 Danish Institute for Human Rights, supra note 31, p. 2.

34 Binderup and Lassen, supra note 21, p. 431.

35 Ibid., pp. 448-451. 
In his report on Denmark, the Special Rapporteur on freedom of religion or belief recommended an abolition of the blasphemy law. According to Bielefeldt, a legal ban on blasphemy 'sits uneasily with the general policy adopted by EU Member States to call for repealing blasphemy laws worldwide.' ${ }^{36}$

The blasphemy law's longstanding status as dormant came to an abrupt end in February 2017. The Director of Public Prosecution decided to allow that charges on the basis of the blasphemy provision were raised against one individual, who in December 2015 released a video on Facebook in which he burned the Quran. In March 2017, in response to this, the political party Red-Green Alliance presented a draft bill on the abolition of the blasphemy ban to Parliament. ${ }^{37}$ The coalition parties in the government reconsidered the latest decision of 2015 not to abolish the provision; in June 2017, Parliament abolished the ban on blasphemy. ${ }^{38}$

\subsection{Current Debates and Tendencies}

New limitations to freedom of religion or belief are continually being debated. This applies, for instance, to prayer rooms in hospitals and educational institutions, and the use of the headscarf in public spaces and in the employment sphere. ${ }^{39}$

A substantial part of the debate takes as its point of departure the view that Muslim practices are not consistent with society's values and ways of functioning. This was, for instance, the case with a statement by the Minister of Integration in a 2018 newspaper blog. During the period of Ramadan, the Minister questioned whether an old religious commandment to fast was compatible with modern society and the labour market in Denmark. Ramadan, in the minister's view, would have negative effects on safety and productivity. She suggested therefore that Muslims take their holidays in this period-in order to prevent Ramadan from having 'a negative effect on the rest of society. 40 The minister's claim about productivity and safety risks was subsequently contradicted, not least by medical doctors among other professionals. ${ }^{41}$

$36 \quad$ Bielefeldt, supra note 3, para. 56 .

37 Justitsministeriet, Forslag til lov om cendring af straffeloven (Ophcevelse af straffelovens blasfemibestemmelse), No. 675 (København, 8 June 2017).

$38 \quad$ Ibid.

39 As of 2009 judges are required not to appear in Danish courts in a way that indicates a political or religious attitude or affiliation; women wearing headscarves were the focus of the debates preceding the new regulation. Folketinget, Forslag til Lov om cendring af retsplejeloven (Dommeres fremtrceden i retsmøder), No. 98 (København, 29 May 2009).

$40 \quad$ Inger Støjberg, 'Nu er det ramadan, og jeg vil gerne slå tre ting fast', BT, 21 May 2018.

41 Mynthe Villadsen, 'Bente Klarlund om Støjbergs kritik af ramadanfastende på arbejde:Jeg kører gerne med en buschauffør der faster', Politiken, 21 May 2018. 
Another debate took place in September 2018 in the media, revolving around the question whether "Muslim believers" should be able to acquire citizenship. The debate was spurred by a suggestion from a newly formed political party (not in Parliament), that 'Citizenship requires assimilation'.42 Debates in the media and among politicians about such interventions in religious traditions may result in a feeling of "us-them" dichotomy, between religious minorities and the majority population. Religious minorities may feel intimidated by the discourse of the media and the politicians (typically representing, in religious terms, the majority population). This applies notably to the debate about boys' circumcision (a Jewish and Muslim practice), a debate that has taken place across a number of European States, including Denmark.

\subsubsection{Debating Male Circumcision for Religious Reasons}

The Jewish community in Denmark has regularly expressed concern that a prohibition of male circumcision would threaten the very existence of Jewish life in Denmark because of the centrality of this ritual for Jewish identity. ${ }^{43}$ They have also expressed the view that many Danish Jews feel less at home in their own country as a result of this debate. ${ }^{44}$ In 2015, the Advisory Committee on the Framework Convention for the protection of national minorities encouraged 'the authorities to continue, together with the groups concerned, to search for pragmatic solutions to the issue of circumcision of boys, taking the health of children fully into account, while ensuring that the outcome does not unduly interfere with the practice of religious traditions at issue.45

In 2018, a Citizens' Proposal ("Borgerforslag") suggested that Parliament ban circumcision of boys except for medical reasons. The proposal referred to the Convention on the Rights of the Child, Articles 19 and 24(3) (regarding the abolition of harmful traditions) and focusses not on freedom of religion or belief, but the physical integrity and autonomy of the child. ${ }^{46}$ The ensuing debate was

42 Danske statsborgerskaber kastes i grams, 27 April 2018, Nye Borgerlige, <https://nyeborger lige.dk/danske-statsborgerskaber-kastes-i-grams/>, accessed 16 May 2019.

43 Dan Rosenberg Asmussen, 'Henvendelse fra Det Jødiske Samfund om borgerforlag mod omskæring', Kirkeudvalget, 5 April 2018, <www.ft.dk/samling/20171/almdel/KIU/bi lag/34/1877258.pdf>, accessed 16 May 2019 .

44 This was, for instance, observed by Heiner Bielefeldt on his country visit to Denmark. Bielefeldt, supra note 3, para. 6.

45 Council of Europe, The Advisory Committee on the Framework Convention for the protection of national minorities Recommendation (20 January 2019).

46 Indførelse af 18 års mindstealder for omskcering af raske børn, <www.borgerforslag.dk/se-og -stoet-forslag/?Id=FT-oo124>, accessed 15 May 2019. 
extensive. In April, the government stated that it would not support a ban. ${ }^{47}$ The Citizens' Proposal was debated in Parliament in the Autumn of 2018, at which point there was not widespread parliamentary support for the proposal. It was then referred to a Parliamentary committee for further consideration. ${ }^{48}$

\subsubsection{Increase in Religiously Motivated Harassment and Hate Crime}

A high level of religiously motivated hate crimes and incidences of Antisemitism and Islamophobia augment the vulnerability of Jews and Muslims. A report by the Danish Security and Intelligence Service (PET) reveals that these crimes and related incidences are primarily targeting religious symbols or localities. $^{49}$ As in many other EU Member States, there is an increased tendency of Antisemitism in Denmark. ${ }^{50}$ In December 2018, the EU Agency for Fundamental Rights, FRA, published a report entitled 'Experiences and Perceptions of Antisemitism?Second Survey on Discrimination and Hate Crime against Jews in the EU, ${ }^{51}$ presenting the results of an extensive survey of $12 \mathrm{EU}$ Member States, including Denmark. ${ }^{52}$ A majority of the Danish respondents considered Antisemitism to be a big or very big problem and, in addition, a growing problem.

\subsection{Summary of Findings}

Freedom of religion or belief is respected to a very high degree in Denmark, and not many limitations are imposed. However, in recent years, an increasing number of legal measures have been taken which limit or potentially limit freedom of religion or belief. Primarily although not exclusively, these measures affect religious minorities, primarily non-Christian minorities (for instance the prohibition on ritual slaughter and the "burka-ban"). Taken separately, a restriction of religious manifestation is not necessarily invasive or expansive.

47 Ritzau, 'Regeringen siger nej til aldersgrænse for omskæring af drenge', Kristeligt Dagblad, 20 April 2018.

48 Folketinget, $B$ g Forslag til folketingsbeslutning om indførelse af 18-årsmindstealder for omskcering af raske børn (borgerforslag), <www.ft.dk/samling/20181/beslutningsforslag/b9/ index.htm>, accessed 15 May 2019.

49 See Danish Institute for Human Rights, supra note 5, pp. 22-24.

$5^{\circ}$ European Union Agency for Fundamental Rights, Antisemitism: Summary overview of the situation in the European Union 2003-2013 (Vienna: Publications Office of the European Union, 2014).

51 European Union Agency for Fundamental Rights, Experiences and perceptions of antisemitism. Second survey on discrimination and hate crime against Jews in the EU (Luxembourg: Publications Office of the European Union, 2018).

$5^{2}$ The Danish respondents totalled 592 (of a population of approximately 7000 Jews). This was the largest percentage of Jewish populations in the entire survey. 
Taken in their entirety, however, individuals and groups belonging to religious minorities may see their freedom seriously limited or attacked because of the accumulation of possible limitations on their religious freedom. This situation is accentuated on the one hand by public debates, which not infrequently show hostility towards religious practices of religious minorities, and on the other hand by the prevalence of hate speech and the occurrence of racism.

From a cumulative standpoint it is possible to trace a perhaps excessive juridification of freedom of religion or belief in Denmark, using the margin of appreciation employed by the ECtHR to limit freedom of religion, without taking into full account the values underlying freedom of religion or belief according to international human rights standards. This leads to a number of questions, not least this one: whether a growing juridification bears the risk that Denmark puts too little emphasis on religious tolerance and inclusion, as they are embedded in international standards.

The ECtHR has affirmed the principle of subsidiarity and the doctrine of margin of appreciation vis-à-vis freedom of religion in a number of cases, especially since 2015. In the words of Malcolm Evans, this points 'in the general direction of an approach which prioritizes the assessment made by the state itself concerning how best to ensure that an appropriate balance is struck between the competing interests at stake, rather than looking to the articulation of international standards or approaches'.53 According to Evans, this indicates a 'general weakening of any "international consensus" concerning the contours of the right and its practical implications. ${ }^{54}$

This development was further cemented by the Copenhagen Declaration on the reform of the System of the European Convention on Human Rights, adopted by the 47 Member States of the Council of Europe in April 2018, following a High Level Conference meeting in Copenhagen at the initiative of the Danish Chairmanship of the Ministers of the Council of Europe. ${ }^{55}$ The Declaration cements the principle of subsidiarity and margin of appreciation, with the conference welcoming the further development of the principle of subsidiarity and the doctrine of the margin of appreciation by the Court in its jurisprudence'. ${ }^{56}$ At the same time, the Declaration states that the conference:

53 Malcolm Evans, 'Challenging Conventional Assumptions: The Case for a Preventive Approach to the Protection of the Freedom of Religion or Belief', in: Evans, Petkoff \& Rivers (eds.), The Changing Nature of Religious Rights under International Law (Oxford: Oxford University Press. 2015), p. 31.

$54 \quad$ Ibid., p. 32.

55 Council of Europe, Copenhagen Declaration on the reform of the System of the European Convention on Human Rights (CoE, 2018).

$56 \quad$ Ibid., para. 31 . 
[w]elcomes the Court's continued strict and consistent application of the criteria concerning admissibility and jurisdiction, including by requiring applicants to be more diligent in raising their Convention complaints domestically, and making full use of the opportunity to declare applications inadmissible where applicants have not suffered a significant disadvantage..$^{57}$

\section{The Way Forward: Systematic Inclusion of Relevant Actors and Increased Use of Soft Law}

The reason why States are given the above-mentioned wide margin of appreciation is that the State is presumably better equipped to understand the local situation in the context of given human rights, such as the freedom of religion or belief. It follows that the State must consider the implications for those affected by limitations to freedom of religion or belief. The Copenhagen Declaration emphasises the need to involve a wide range of actors:

Effective national implementation requires the engagement of, and interaction between, a wide range of actors to ensure that legislation, and other measures and their application in practice comply fully with the Convention. These include, in particular, members of government, public officials, parliamentarians, judges and prosecutors, as well as national human rights institutions, civil society, universities, training institutions and representatives of the legal professions. ${ }^{58}$

Such inclusion, which may for instance take the form of making more use of briefs submitted to Parliament, may support the State in its assessment and sustain the principle of the margin of appreciation as employed by the Strasbourg Court. In relation to freedom of religion or belief this would also entail systematic inclusion of relevant faith communities and representatives as well as experts prior to concrete initiatives, including legal regulation of religious manifestations, and initiatives to combat radicalisation and religious extremism.

With regard to the use of soft law, created under the auspices of the EU, the Council of Europe and the UN, it is suggested that Danish policy-makers would benefit from making increased use of this tool in the area of freedom of religion or belief. This would facilitate a comprehensive and substantive

$57 \quad$ Ibid., para. 32 .

$5^{8}$ Ibid., para. 14. See also para. 33, regarding the role of civil society vis-à-vis the ECtHR. 
understanding as well as the implications of potential limitations to this freedom for society and individuals.

An example par excellence is Heiner Bielefeldt's country visit to Denmark in 2016. The Special Rapporteur's report offers recommendations that aim to find solutions to current challenges without limiting freedom of religion or belief, from the perspective of international human rights standards and in the context of societal values and developments. The report largely revolves around the concept of inclusive democracy and the need for the government to take a leading part in developing an inclusive society-where Muslims and Jews and those who identify with other faiths do not feel stigmatised but rather equal members of society. 59

The approach of the UN Special Rapporteur-which is profoundly valuesbased rather than merely based on legal analyses-fits surprisingly well into the EU's attempts to promote freedom of religion or belief in Member States by means of soft-law tools, such as dialogues. At the moment, there is no political agreement among EU member states to increase the protection of the rights of religious minorities by means of more EU directives or other legislative measures; however, non-legally binding initiatives under the auspices of the EU are frequent..$^{60}$ One example is the Declaration on the fight against antisemitism and the development of a common security approach to better protect Jewish communities and institutions in Europe, approved by the Council of the EU in December 2018. In this declaration, the Council acknowledges that Jewish communities in some EU countries feel particularly vulnerable to terrorist attacks, following an increase in violent incidents in recent years. It notes that anti-Semitic hatred remains widespread and is increasing in EU Member States, as confirmed by the 2018 Fundamental Rights Agency Report on antiSemitism. The declaration invites Member States to adopt and implement a holistic approach to prevent and fight all forms of antisemitism, as part of their strategies on preventing racism, xenophobia, radicalisation and violent extremism. It calls on Member States to increase their efforts to ensure security for Jewish communities, institutions and citizens. ${ }^{61}$

59 Bielefeldt, supra note 3, para. 75(b)-(d): '(b) The Government should send clear and unambiguous messages that all people living in Denmark, including members of religious minorities, should feel safe and at home in the country. These messages should promptly and strongly counter the increasing idea that "Islam is a threat to Danish identity"; (c) In integration programmes, the Government should explore the dimensions of religious community life as a positive resource for strengthening intragroup and intergroup solidarity ... (d) In order to prevent and overcome a climate of suspicion within society, more dialogue seems imperative. Notwithstanding the contributions made by various stakeholders, the Government should take an active facilitating role in that regard.'

6o Lassen, supra note 1, pp. 164-166.

61 Council of Europe, Fight against Antisemitism: Council Declaration (2018). 
The following question remains: what is the likelihood that politicians will make increased efforts to involve civil society and other actors in issues of relevance to freedom of religion or belief? In answering this question, it is noteworthy that a new tendency is emerging from the Folkekirke's particular position in Danish society. The UN Special Rapporteur stressed the need for Denmark to reconsider the privileged position of the Folkekirke, partly because its present construction may reinforce the feeling of inequality among the majority Christians and religious minorities and non-believers. ${ }^{62}$ However, paradoxically, the very fact that Denmark has a Folkekirke can play out in favour of strengthening freedom of religion or belief in Denmark. First of all, the Folkekirke generally favours dialogue-oriented discussions with religious minorities, Christians as well as non-Christians. ${ }^{63}$ Second, on several occasions and sometimes in unison with other churches, important members of the Folkekirke (including individual bishops) have protested against the increased pressure on religious minorities' freedom of religion or belief. ${ }^{64}$ The Folkekirke is a huge part of Danish identity, and therefore the voice of the Folkekirke has an embedded authority vis-à-vis politicians and policy-makers as well as in public debates. Thus, the privileged position of the Folkekirke and the respect it widely holds across Denmark mean that when its members and leaders express values of tolerance and dialogue and acceptance of the co-existence of different religions, such expressions may contribute significantly to ensuring the freedom of religion of religious minorities.

\section{Acknowledgement}

Tore Lindholm, Emeritus Professor (Philosophy) of the Norwegian Institute for Human Rights, has been a very active collaborator on the work leading to this article, and he presented the background report at a meeting organised by the Oslo Coalition on Freedom of Religion or Belief held in Oxford in November 2018. I am very grateful that he let me benefit from his huge knowledge and many insightful suggestions.

62 Bielefeldt, supra note 3, para. 73. See also Lisbet Christoffersen, 'Der er fuld religionsfrihed i Danmark, men ...', 170(2/18) Dansk Kirketidende (2018), pp. 12-18.

63 As also observed by the Special Rapporteur on freedom of religion or belief, Heiner Bielefeldt on his mission to Denmark, Bielefeldt, supra note 3, para. 20.

64 An example is the protest of the board of the National Council of Churches in Denmark against the attempt to criminalise circumcision of boys for religious reasons. Forretningsudvalget i Danske Kirkers Råd, Omskæringsdebatten og frygten for det anderledes, 20 April 2018, <www.danskekirkersraad.dk/omskaeringsdebatten-og-frygtenfor-det-anderledes/> accessed 15 May 2019. 